\title{
Phenological Effects on Forage Quality of Five Grass Species
}

\author{
H. Arzani, ${ }^{1}$ M. Zohdi, ${ }^{2}$ E. Fish, ${ }^{3}$ G. H. Zahedi Amiri, ${ }^{4}$ \\ A. Nikkhah, ${ }^{5}$ and D. Wester 6 \\ Authors are: ${ }^{1}$ Associate Professor, College of Natural Resources, University of Tehran, P.O. Box 31585-4314, Karaj, 31587-Iran; \\ ${ }^{2}$ Researcher, Research Institute of Forests and Rangelands of Iran, P.O. Box 13185-116, Tehran, Iran; \\ ${ }^{3}$ Professor and Head, Department of Range, Wildlife and Fisheries Management, Texas Tech University, Lubbock, TX 79409; \\ ${ }^{4}$ Lecturer, College of Natural Resources, University of Tehran, P.O. Box 31585-4314, Karaj 31587-Iran; \\ ${ }^{5}$ Professor, College of Agricultural Science, University of Tehran, P.O. Box 4111, Karaj 31587-Iran; and \\ ${ }^{6}$ Professor, Department of Range, Wildlife and Fisheries Managament, Texas Tech University, Lubbock, TX 79409.
}

\begin{abstract}
Information on nutritive values of each plant part in each phenological stage could help range managers choose suitable grazing times to achieve higher animal performance without detriment to vegetation. Thus, nutritive value of different plant parts of 5 grass species in 3 phenological stages (vegetative, flowering, and seed production) from 2 sites were investigated. Species included: Agropyron tauri Boiss and Bal., Agropyron trichophorum Richt, Bromus tomentellus Boiss, Festuca ovina Hack, and Hordeum bulbosum L. Samples of leaf, stem, and flower from 5 locations at each site for each species were analyzed for dry matter ratio of plant parts, crude protein, acid detergent fiber, neutral detergent fiber, dry matter digestibility, and metabolizable energy. A completely randomized design with a factorial arrangement of species and phenological stage was analyzed with 5 replicates for each location. Plant part was included as a subplot factor in a split plot arrangement. Nutritive values differed significantly $(P<0.05)$ both within and among plant parts and phenological stages for each species. Phenological stages indicated a significant difference on nutritive value of plant parts, with leaves having the highest nutritive value. Thus, forage with a higher leaf-to-stem ratio should improve animal performance because at the beginning of the 2 nd phenological stage, the plant had desirable quantity and quality of forage with higher leaf-to-stem ratio.
\end{abstract}

\section{Resumen}

La información del valor nutritivo de cada parte de la planta en cada estado fenológico pudiera ayudar a los manejadores de pastizales a elegir las épocas apropiadas de apacentamiento para alcanzar un mayor comportamiento productivo del animal sin detrimento de la vegetación. Se investigó el valor nutritivo de diferentes partes de la planta de 5 especies de zacates en 3 estados fenológicos (vegetativo, floración y producción de semilla) provenientes de dos sitios. Las especies incluidas fueron: Agropyron tauri Boiss y Bal., A. trichophorum Richt, Bromus tomentellus Boiss, Festuca ovina Hack y Hordeum bulbosum L. Muestras de hojas, tallo y flores de cada especie se tomaron en 5 localidades dentro del cada sitio y se analizaron para determinar la relación de materia seca de las partes de la planta, el contenido de proteína cruda, fibra ácido detergente, fibra neutro detergente, digestibilidad de la materia seca y energía metabolizable. El diseño experimental utilizado fue completamente al azar en arreglo factorial, los factores fueron las especies y los estados fenológicos, se tuvieron 5 repeticiones y los análisis fueron por localidad. Las partes de las plantas se incluyeron como subparcelas en un diseño de parcelas divididas. En cada especie, los valores nutritivos difirieron significativamente $(P<0.05)$ dentro y entre las partes de la planta y entre los estados fenológicos. Los estados fenológicos, presentaron una diferencia significativa en el valor nutritivo de las partes de la planta, el mayor valor nutritivo lo tuvo las hojas. Así, el forraje con la mayor relación hoja:tallo deberá mejorar el comportamiento productivo del animal, como al inicio de la segunda etapa fenológica en el que la planta tuvo valores deseables de cantidad y calidad de forraje con la mayor relación hoja:tallo.

Key Words: phenological stages, crude protein, acid detergent fiber, neutral detergent fiber, dry matter digestibility, metabolizable energy

\section{Introduction}

Information on the nutritive value of forage by phenological stage could help range managers choose suitable grazing times

Research was funded by The University of Tehran and the Scientific Research Organization of Iran. The authors gratefully acknowledge Dr Vivien Allen and Mr. Philip Brown for help in editing the manuscript.

Correspondence: Dr Hossein Arzani, College of Natural Resources, University of Tehran, P.0. Box 31585-4314, Karaj, 31587-Iran. Email: harzani@ut.ac.ir

Manuscript received 7 July 2002; manuscript accepted 11 May 2004. and stocking rates to achieve higher animal performance without damage to vegetation. Factors that affect forage quality include species, leaf-to-stem ratio, stage of growth, soil agents, climate, harvesting, diseases, and pests (Harrocks and Valentine 1999; Arzani et al 2001).

McDonald et al (1995) reported that in early spring, digestibility of plants might reach $80 \%$ or higher and will decrease when plant growth is complete. Digestible energy, metabolizable energy, and digestibility of forage decrease, whereas fiber and lignin increase with maturity of plants. Ghoorchi (1995) and Ghadaki et al (1974) reported reduction of crude protein (CP) and digestibility of forage when plants 
matured; however, percentages of acid detergent fiber (ADF) and neutral detergent fiber (NDF) increased. Differences among ratios of plant parts in different phenological stages were reported by Jafari (1993). In the primary growth stage, grass stems are short and ratios of leaf to stem are high. When plant growth is complete, stems comprise a major part of the total forage (Langer 1979).

In this study, the forage quality of stems, leaves, and flowers of 5 grasses in 3 phenological stages (vegetative, flowering, and completed growth) was determined and compared.

\section{Material and Methods}

This study was conducted in the Zaghe region of the Zagros mountains on the right-hand side of the Khoramabad-Brojerd highway in Lorestan Province of Iran, 30 to $40 \mathrm{~km}$ northeast of the capital city of Khoramabad. Mean relative humidity was $54 \%$, average annual temperature was $18.5^{\circ} \mathrm{C}$, there were 119 freezing days, and annual precipitation was $742 \mathrm{~mm}$.

Exclosures on 2 of the sites, $5 \mathrm{~km}$ apart, were selected for sample collection. Soils were classified as Entisols (orchrepts suborder) on the basis of the US Department of Agriculture method of classification with loamy-clay texture (Hemmati 1997).

The 1st site ( $3 \mathrm{ha}$ ) was located on a southwest to northeast aspect and had been excluded from grazing since 1969. Average elevation was $1960 \mathrm{~m}$ above sea level.

Dominant species were Festuca ovina Hack and Bromus tomentellus Boiss. Other species were Hordeum bulbosum L., Agropyron elongatom (Host) P. Beauv, Agropyron trichophorum Richt, Agropyron tauri Boiss and Bal., Poa bulbosa L., Secale montanum Guss, Aegilops cylindrica Host, Biossiera squarrosa Banks and Soland, Psatyrostachys fragil Boiss, Eryngium caucasicum Trautv, Astragalus spp. Scariola orientalis Boiss, Stachys koelzii Rech. F., Thymus kotschyanus Boiss and Hohen, Sanguisorba minor Scop, Achillea vermicularis tyin, Gundelia tourneforti L., Vicia villosa Roth, and Vicia orientalis Beg and Diratz.

The 2 nd site (a 20-ha exclosure) was located on a northwest aspect and had been excluded from grazing since 1995. Its average elevation was $2200 \mathrm{~m}$ above sea level. Dominant species were Astragalus verus and $F$. ovina. In addition to species mentioned for site 1, Stachys inflata, Daphne oleoides, Astragauls ascendens, Hetranthelium piliferum, Minuartia aizoides, and Crataegus pojark (tree) were also observed on this site. Because of the higher elevation, plant growth was delayed relative to site 1 . Soil was lighter (clay loam) and shallower than the soil at the 1 st site.

Five grasses common to both sites (A. tauri, A. trichophorum, Bromus tomentellus, F. ovina and $H$. bulbosum) were selected for study. These species are observed in most mountain rangelands of Iran, are relatively palatable to domestic grazing animals, and are able to regrow after grazing or harvesting. They belong to the subfamily Pooidea. Among them, H. bulbosum, A. tauri, and $A$. trichophorum belong to the class Triticeae, F. ovina belongs to Festuceae, and $B$. tomentellus belongs to Bromeae (Mobayen 1980). Samples were collected in 3 phenological stages: 1) primary growth (rapid growth, vegetative), 2) flowering, and 3) seed production (plant growth completed). At each site, 5 points were randomly selected for sample collections of each species. Plants were cut $1 \mathrm{~cm}$ above ground. Plant parts (leaf, stem, flower) were separated, oven dried at $70^{\circ} \mathrm{C}$ for 24 hours, and weighed. Ratios of each part to total weight (RP/TW) were determined. Finally, samples were ground by a mill and passed through a $0.5-\mathrm{mm}$ sieve for chemical analysis.

$\mathrm{CP}$ was calculated on the basis of nitrogen percentage $(\mathrm{N} \% * 6.25)$ measured by the Kjeldahl technique (AOAC 1980). It was multiplied by a factor of 10 to convert to grams per kilogram. ADF and NDF $(\mathrm{g} / \mathrm{kg})$ were measured with the Fiber Tech System (AOAC 1980). Dry matter digestibility was estimated by the formula $\mathrm{DMD} \%=83.58-0.824 \mathrm{ADF} \%+2.626 \mathrm{~N} \%$ suggested by Oddy et al (1983). Metabolizable energy was predicted with the equation $\mathrm{ME}=0.17 \mathrm{DMD} \%-2$ suggested by AOAC (1980).

Effects of species and phenological stage were analyzed in a factorial arrangement of a completely randomized design with 5 replications of each species collected for each stage at each site. Each plant yielded information on 2 (leaf and stem in phenological stages 1,2 , and 3 ) or 3 (leaf, stem, and flower in stages 2 and 3) plant parts; thus, plant part was included in the analysis as a subplot factor in a split plot arrangement. Locations were combined into 1 analysis following Cochran and Cox (1957). When factors interacted, simple effects were analyzed with a least significant difference test.

\section{Results}

For all 6 quality components (RP/TW, CP, ADF, NDF, DMD, $\mathrm{ME})$, the 3-way interaction among species, phenological stage, and plant part was significant; simple effects of each factor were analyzed. Location was not significant and did not interact with any other factor in any analysis.

Leaves were the main part of forage weight in the 1st growth stage (Table 1). Among species, the highest percentage of leaves was recorded for B. tomentellus- $94.3 \%$ of its total forage weight in the 1st phenological stage. At the same growth stage, the lowest percentage of leaves belonged to A. trichophorum, which was $64.3 \%$ of its total weight.

In the 2 nd growth stage, flowers became a part of total forage weight. In this stage, ratios of stems to total weight were higher than in the 1st stage (Table 1). However, in the 2nd stage, the ratio of leaves to total forage weight was still higher than stem and flower ratios for A. tauri, F. ovina, H. bulbosum, and $B$. tomentellus. For $A$.trichophorum, the ratio of stems to total forage weight was higher than for leaves or flowers.

In the 3rd phenological stage, ratios of leaves to total weight were higher than stems for $A$. tauri and $F$. ovina. However, for other species, higher ratios were obtained for stems. Different conditions were found for flowers that were related to anatomic characteristics of each species. Higher ratios of flowers were recorded for A. trichophorum and B. tomentellus compared with their 2nd phenological stage growth. Thus, ratios of flowers to total weight were lower than ratios of leaves and stems in both stages. No significant difference of flower ratios was recorded for A. tauri in the 2 nd and 3rd growth stages. In this species, flowers also contributed small amounts of forage compared with leaves and stems. For $F$. ovina and $H$. bulbosum, ratios of flowers to total weight in the 3rd phenological stage were lower compared with the 2 nd stage. 
Table 1. Changes in plant component percentages (stems, leaves, and flowers) for Agropyron tauri (Agta), Agropyron trichophorum (Agtr), Bromus tomentellus (Brto), Festuca ovina (Feov), and Hordeum bulbosum (Hobu) between species within and among phenological stages.

\begin{tabular}{|c|c|c|c|c|c|c|c|c|}
\hline \multirow[b]{3}{*}{ Species } & \multicolumn{5}{|c|}{ Plant component $(\%)^{1}$} & \multicolumn{3}{|l|}{. } \\
\hline & \multicolumn{2}{|c|}{ Vegetative } & \multicolumn{3}{|c|}{ Flowering } & \multicolumn{3}{|c|}{ Maturity } \\
\hline & Leaf & Stem & Leaf & Stem & Flower & Leaf & Stem & Flower \\
\hline Agta & $89.4 \mathrm{aAxV}$ & $11.5 \mathrm{bAx}$ & $56.0 \mathrm{aBx}$ & $31.1 \mathrm{bBx}$ & $13.0 \mathrm{cAw}$ & $43.5 \mathrm{aCx}$ & $43.0 \mathrm{aCw}$ & $13.5 \mathrm{bAx}$ \\
\hline Agtr & 64.3 aAw & $35.8 \mathrm{bAw}$ & $39.7 \mathrm{aBw}$ & $43.3 \mathrm{aBw}$ & $17.0 \mathrm{bAw}$ & $37.4 \mathrm{aBw}$ & $43.3 \mathrm{bCw}$ & $19.3 \mathrm{cAw}$ \\
\hline Brto & $94.3 \mathrm{aAx}$ & $5.7 \mathrm{bAz}$ & $50.2 \mathrm{aBz}$ & $32.5 \mathrm{bBx}$ & $17.3 \mathrm{cAw}$ & $34.0 \mathrm{aCx}$ & $45.7 \mathrm{bCw}$ & $21.3 \mathrm{cAw}$ \\
\hline Feov & $78.2 \mathrm{aAy}$ & $19.0 \mathrm{bAy}$ & $61.3 \mathrm{aBy}$ & $22.6 \mathrm{Ay}$ & $16.2 \mathrm{cAw}$ & 63.7 aBy & $25.2 \mathrm{bBy}$ & $11.1 \mathrm{cAx}$ \\
\hline Hobu & $86.1 \mathrm{aAv}$ & $13.9 \mathrm{bAx}$ & $46.5 \mathrm{aBz}$ & $29.37 \mathrm{bBx}$ & $24.2 \mathrm{bAv}$ & $18.9 \mathrm{aCv}$ & $60.5 \mathrm{bCv}$ & 20.6 aAw \\
\hline
\end{tabular}

${ }^{1}$ Plant part means within a species and a phenological stage followed by the same lowercase letter $(\mathrm{a}, \mathrm{b}, \mathrm{c})$ are not significantly different $(P>0.05)$. Phenological stage means within a species and a plant part followed by the same uppercase letter $(A, B, C)$ are not significantly different $(P>0.05)$. Species means within a phenological stage and a plant part followed by the same lowercase letter $(v, w, x, y, z)$ are not significantly different $(P>0.05)$.

In $F$. ovina, flowers did not make up a considerable part of forage weight in either the 2 nd or 3 rd stages. Stems were the main part of forage for $H$. bulbosum $(60.5 \%)$ in the 3 rd phenological stage. In this stage, leaves represented $18.9 \%$ and flowers $20.6 \%$ of the total forage weight.

$\mathrm{CP}$ was reduced in stems and flowers of all species with growth progression (except for stems of $A$. trichophorum in the 1st and 2nd stages; Table 2). CP also decreased in leaves of $A$. tauri and $B$. tomentellus with growth. Maximum and minimum values of $\mathrm{CP}$ were observed in $F$. ovina and $H$. bulbosum in the 2nd and 3rd phenological stages, respectively. CP values of leaves in the 1 st and 2 nd growth stages for $F$. ovina and $A$. trichophorum were not significantly different. Highest $\mathrm{CP}$ was recorded for stems of $H$. bulbosum in the 1 st phenological stage $(122 \mathrm{~g} / \mathrm{kg})$ and the lowest for stems of the same species in the 3rd phenological stage $(18 \mathrm{~g} / \mathrm{kg})$. Maximum CP was found in leaves of $B$. tomentellus $(150 \mathrm{~g} / \mathrm{kg})$ in the 1 st phenological stage, and the minimum was in leaves of $H$. bulbosum $(26 \mathrm{~g} / \mathrm{kg})$ in the 3rd phenological stage (Table 2).

Among flowers, $H$. bulbosum showed highest CP (133 g/kg) in the 2nd phenological stage, and flowers belonging to $A$. trichophorum showed lowest values $(56 \mathrm{~g} / \mathrm{kg})$ in the 3rd growth stage. The range of variation of $\mathrm{CP}$ in leaves, stems, and flowers of $H$. bulbosum was more extreme than in other species.

ADF in stems and leaves of all species was lower in the 1st phenological stage and higher in the 3rd stage (Table 3). However, variation of ADF in flowers were not regular, which was related to differences of seed weight of species. In A. tauri, B. tomentellus, and H. bulbosum, ADF in the 2 nd phenological stage of growth was higher than in the 3rd stage. For $A$. trichophorum and $F$. ovina, ADF in the 3 rd phenological stage was higher than in the 2 nd.

Highest ADF was recorded from stems of $B$. tomentellus $(552 \mathrm{~g} / \mathrm{kg})$ in the $3 \mathrm{rd}$ phenological stage, and the minimum (331 $\mathrm{g} / \mathrm{kg}$ ) for the same species was found in the 1 st stage (Table 3 ). Variation of ADF of B. tomentellus' stems between phenological stages was greater than for other species. Leaves of $B$. tomentellus contained the lowest ADF in the 1st phenological stage $(154 \mathrm{~g} / \mathrm{kg})$, whereas leaves of $H$. bulbosum showed the highest ADF in the $3 \mathrm{rd}$ stage $(415 \mathrm{~g} / \mathrm{kg}$ ).

Flowers were absent in the 1 st stage of phenology (Table 3 ). Highest ADF was obtained in flowers of A. trichophorum $(430 \mathrm{~g} / \mathrm{kg})$ in the $3 \mathrm{rd}$ phenological stage, and the lowest belonged to flowers of F. ovina $(334 \mathrm{~g} / \mathrm{kg})$ in the 2 nd stage of phenology. Variation of ADF in flowers was the highest in $A$. trichophorum.

NDF in leaves and stems of $A$. tauri, A. trichophorum, B. tomentellus, and $H$. bulbosum increased as plant growth progressed (Table 4). Stem NDF in F. ovina similarly increased; however, leaf NDF in the 2nd stage of phenology was slightly higher than in the 3 rd stage.

NDF of flowers in A. tauri, A. trichophorum, and $H$. bulbosum was higher in the 3rd stage of growth (Table 4). However, in the other species, it was higher in the 2nd

Table 2. Variation in crude protein (CP, g/kg) between species and within and among plant parts and phenological stages of Agropyron tauri (Agta), Agropyron trichophorum (Agtr), Bromus tomentellus (Brto), Festuca ovina (Feov), and Hordeum bulbosum (Hobu).

\begin{tabular}{|c|c|c|c|c|c|c|c|c|}
\hline \multicolumn{9}{|c|}{ Variation in $\mathrm{CP}(\mathrm{g} / \mathrm{kg})^{1}$} \\
\hline \multirow[b]{2}{*}{ Species } & \multicolumn{2}{|c|}{ Vegetative } & \multicolumn{3}{|c|}{ Flowering } & \multicolumn{3}{|c|}{ Maturity } \\
\hline & Leaf & Stem & Leaf & Stem & Flower & Leaf & Stem & Flower \\
\hline Agta & 119 aAw & $63.7 \mathrm{bAw}$ & $84 \mathrm{aBw}$ & $49 \mathrm{bBw}$ & 70 cAw & $40 \mathrm{aCw}$ & $38 \mathrm{aCw}$ & $57 \mathrm{cBw}$ \\
\hline Agtr & $97 \mathrm{aAx}$ & $54 \mathrm{bAx}$ & $97 \mathrm{aAx}$ & 54 bAw & $78 \mathrm{CAx}$ & $33 \mathrm{aBx}$ & $33 \mathrm{bBwy}$ & $56 \mathrm{cBw}$ \\
\hline Brto & $150 \mathrm{aAz}$ & $84 \mathrm{bAz}$ & $141 \mathrm{aBz}$ & $70 \mathrm{bBz}$ & $104 \mathrm{CAZ}$ & $62 \mathrm{aCz}$ & $19 \mathrm{bCz}$ & $87 \mathrm{cBz}$ \\
\hline Feov & $94 \mathrm{aAx}$ & 67 bAw & 96 aAyx & $60 \mathrm{bBy}$ & $127 \mathrm{CAy}$ & $52 \mathrm{aBy}$ & $29 \mathrm{bCy}$ & $63 \mathrm{cBy}$ \\
\hline Hobu & $139 \mathrm{aAv}$ & 122 bAv & 145 aBy & $71 \mathrm{bBz}$ & $133 \mathrm{CAv}$ & $26 \mathrm{aCy}$ & $18 \mathrm{aCz}$ & $71 \mathrm{cBv}$ \\
\hline
\end{tabular}


Table 3. Variation in acid detergent fiber (ADF, g/ $/ \mathrm{kg}$ ) between species and within and among plant parts and phenological stages of Agropyron tauri (Agta), Agropyron trichophorum (Agtr), Bromus tomentellus (Brto), Festuca ovina (Feov), and Hordeum bulbosum (Hobu).

\begin{tabular}{|c|c|c|c|c|c|c|c|c|}
\hline \multicolumn{9}{|c|}{ Variation in ADF $(g / \mathrm{kg})^{1}$} \\
\hline \multirow[b]{2}{*}{ Species } & \multicolumn{2}{|c|}{ Vegetative } & \multicolumn{3}{|c|}{ Flowering } & \multicolumn{3}{|c|}{ Maturity } \\
\hline & Leaf & Stem & Leaf & Stem & Flower & Leaf & Stem & Flower \\
\hline Agta & 329 aAwx & 383 bAy & 357 aBxy & 437 bBy & $406 \mathrm{cAw}$ & $415 \mathrm{aBCw}$ & $457 \mathrm{bCw}$ & $391 \mathrm{aAw}$ \\
\hline Agtr & $345 \mathrm{aAw}$ & 388 bAy & $374 \mathrm{aBx}$ & 452 bBy & $423 \mathrm{cAw}$ & $390 \mathrm{aBxz}$ & $466 \mathrm{bBw}$ & $430 \mathrm{cAx}$ \\
\hline Brto & $154 \mathrm{aAz}$ & $331 \mathrm{bAz}$ & $304 \mathrm{aBz}$ & $488 \mathrm{bBx}$ & $383 \mathrm{cAz}$ & $405 \mathrm{aCzw}$ & $552 \mathrm{bCz}$ & $308 \mathrm{cBz}$ \\
\hline Feov & 320 aAxy & $416 \mathrm{bAx}$ & 351 aBy & $497 \mathrm{bBx}$ & $334 \mathrm{cAy}$ & $378 \mathrm{aCx}$ & $521 \mathrm{bCy}$ & 371 aBy \\
\hline Hobu & 308 aAy & $331 \mathrm{bAz}$ & 351 aBy & 447 bBy & $341 \mathrm{aAy}$ & $415 \mathrm{aCw}$ & 534 bCy & $339 \mathrm{cAv}$ \\
\hline
\end{tabular}

phenological stage. Maximum NDF of stems was obtained for $H$. bulbosum when plant growth was fully developed $(787 \mathrm{~g}$ ) $\mathrm{kg})$. Lowest NDF content of stems was recorded for B. tomentellus $(499 \mathrm{~g} / \mathrm{kg})$ during its primary growth. The NDF content of leaves of $A$. tauri was $672 \mathrm{~g} / \mathrm{kg}$ in the $3 \mathrm{rd}$ phenological stage and $506 \mathrm{~g} / \mathrm{kg}$ in leaves of $B$. tomentellus in the 1st stage.

Dry matter digestibility of stems and leaves of all species was reduced with growth (Table 5). Dry matter digestibility of flowers in A. tauri and B. tomentellus in the 3rd phenological stage was higher than in the 2 nd stage. It was slightly higher in the 2 nd stage of growth for A. trichophorum, F. ovina, and H. bulbosum.

Highest DMD was recorded for stems of H. bulbosum $(614$ $\mathrm{g} / \mathrm{kg}$ ) in the 1st phenological stage, whereas the lowest DMD was found for stems of $B$. tomentellus $(389 \mathrm{~g} / \mathrm{kg})$ in the $3 \mathrm{rd}$ growth stage.

Maximum DMD of leaves was recorded for $B$. tomentellus in its primary phenological stage $(772 \mathrm{~g} / \mathrm{kg}$ ) and minimum for leaves of $H$. bulbosum when its growth was completed $(505 \mathrm{~g} / \mathrm{kg}$ ).

Flowers of $B$. tomentellus were associated with the higher DMD $(619 \mathrm{~g} / \mathrm{kg})$ than A. trichophorum $(508 \mathrm{~g} / \mathrm{kg})$ when growth of all species was completed. The results indicated significant differences between DMD of leaves, stems, and flowers for all species. However, DMD of leaves and flowers in the 3 rd phenological stage for $F$. ovina and for H. bulbosum in the 2nd stage were not significantly different. Variation of DMD for B. tomentellus was higher than for other species.

Metabolizable energy of stems and leaves of all species declined with growth (Table 6). In the 3rd phenological stage, $\mathrm{ME}$ of flowers for 3 species was lower than in the 2 nd stage. However, ME of flowers in A. tauri and B. tomentellus in the 3rd stage was slightly higher than in the 2nd stage of phenology.

Maximum ME was measured for stems of $H$. bulbosum in the 1 st phenological stage $(8.4 \mathrm{MJ} / \mathrm{kg} \mathrm{DM})$, and minimum ME was obtained from stems of $B$. tomentellus when its growth was completed $(4.6 \mathrm{MJ} / \mathrm{kg})$. The highest amount of $\mathrm{ME}$ was recorded for leaves in $B$. tomentellus $(11.1 \mathrm{MJ} / \mathrm{kg})$ and the lowest in leaves of $H$. bulbosum $(6.6 \mathrm{MJ} / \mathrm{kg})$ in the 1 st and $3 \mathrm{rd}$ phenological stages, respectively.

The highest ME content was found in flowers belonging to B. tomentellus $(8.5 \mathrm{MJ} / \mathrm{kg})$, and the lowest value was obtained from flowers of A. trichophorum $(6.6 \mathrm{MJ} / \mathrm{kg})$ in the $3 \mathrm{rd}$ stage of phenology.

\section{Discussion}

Although Arzani et al (2001) reported that locations had significant effects on forage quality in their research because of differences in soil and climate characteristics, selected sites in this research were located in the same vegetation commu-

Table 4. Variation in neutral detergent fiber (NDF, $\mathrm{g} / \mathrm{kg}$ ) between species and within and among plant parts and phenological stages of Agropyron tauri (Agta), Agropyron trichophorum (Agtr), Bromus tomentellus (Brto), Festuca ovina (Feov), and Hordeum bulbosum (Hobu).

\begin{tabular}{|c|c|c|c|c|c|c|c|c|}
\hline \multirow[b]{3}{*}{ Species } & \multicolumn{7}{|c|}{ Variation in NDF $(\mathrm{g} / \mathrm{kg})^{1}$} & \\
\hline & \multicolumn{2}{|c|}{ Vegetative } & \multicolumn{3}{|c|}{ Flowering } & \multicolumn{3}{|c|}{ Maturity } \\
\hline & Leaf & Stem & Leaf & Stem & Flower & Leaf & Stem & Flower \\
\hline Agta & 567 aAw & 636 bAw & $624 \mathrm{aBw}$ & $663 \mathrm{bBw}$ & $670 \mathrm{cAw}$ & $672 \mathrm{aBw}$ & $706 \mathrm{bCw}$ & $704 \mathrm{cAw}$ \\
\hline Agtr & $591 \mathrm{aAx}$ & $673 \mathrm{bAx}$ & $608 \mathrm{aBx}$ & $691 \mathrm{bBx}$ & $661 \mathrm{bAx}$ & $625 \mathrm{aCx}$ & $701 \mathrm{bBw}$ & $696 \mathrm{cBx}$ \\
\hline Brto & $506 \mathrm{aAz}$ & $499 \mathrm{aAz}$ & $528 \mathrm{aBz}$ & $703 \mathrm{bBx}$ & $607 \mathrm{cAz}$ & $556 \mathrm{aCz}$ & $738 \mathrm{bCz}$ & $601 \mathrm{cBz}$ \\
\hline Feov & 455 aAy & 662 bAx & 588 aBy & 726 bBy & $663 \mathrm{cAx}$ & $561 \mathrm{aCz}$ & 729 bBy & $636 \mathrm{cBy}$ \\
\hline Hobu & $519 \mathrm{aAv}$ & $647 \mathrm{bAw}$ & $566 \mathrm{aBv}$ & $678 \mathrm{bBv}$ & $641 \mathrm{bAx}$ & $656 \mathrm{aCv}$ & $787 \mathrm{bCv}$ & $700 \mathrm{aBv}$ \\
\hline
\end{tabular}


Table 5. Variation in dry matter digestibility $(\mathrm{g} / \mathrm{kg})$ between species and within and among plant parts and phenological stages of Agropyron tauri (Agta), Agropyron trichophorum (Agtr), Bromus tomentellus (Brto), Festuca ovina (Feov), and Hordeum bulbosum (Hobu).

\begin{tabular}{|c|c|c|c|c|c|c|c|c|}
\hline \multicolumn{9}{|c|}{ Variation in DMD $(g / \mathrm{kg})^{1}$} \\
\hline \multirow[b]{2}{*}{ Species } & \multicolumn{2}{|c|}{ Vegetative } & \multicolumn{3}{|c|}{ Flowering } & \multicolumn{3}{|c|}{ Maturity } \\
\hline & Leaf & Stem & Leaf & Stem & Flower & Leaf & Stem & Flower \\
\hline Agta & 615 aAw & 547 bAw & 577 aBwy & 496 bBw & $531 \mathrm{cAw}$ & $511 \mathrm{aCw}$ & $475 \mathrm{bCw}$ & $538 \mathrm{CAW}$ \\
\hline Agtr & 593 aAx & 539 bAw & $569 \mathrm{aBw}$ & $486 \mathrm{bBw}$ & $520 \mathrm{cAw}$ & $528 \mathrm{aCx}$ & $466 \mathrm{bCw}$ & $508 \mathrm{cAx}$ \\
\hline Brto & $772 \mathrm{aAz}$ & $599 \mathrm{aAz}$ & $644 \mathrm{aBz}$ & $466 \mathrm{bBz}$ & $564 \mathrm{cAz}$ & $528 \mathrm{aCx}$ & $389 \mathrm{bCz}$ & $619 \mathrm{cBz}$ \\
\hline Feov & 612 aAw & 521 aAy & 586 aBy & $452 \mathrm{bBz}$ & $614 \mathrm{cAy}$ & $546 \mathrm{aCy}$ & 419 bCy & 556 aBy \\
\hline Hobu & $641 \mathrm{aAv}$ & $614 \mathrm{bAv}$ & $607 \mathrm{aBv}$ & $497 \mathrm{bBw}$ & 610 aAy & $505 \mathrm{aCw}$ & $404 \mathrm{bCz}$ & $587 \mathrm{cBv}$ \\
\hline
\end{tabular}

${ }^{1}$ Plant part means within a species and a phenological stage followed by the same lowercase letter $(a, b, c)$ are not significantly different $(P>0.05)$. Phenological stage means within a species and a plant part followed by the same uppercase letter $(A, B, C)$ are not significantly different $(P>0.05)$. Species means within a phenological stage and a plant part followed by the same lowercase letter $(v, w, x, y, z)$ are not significantly different $(P>0.05)$

nity and the same climatic zone, so location had no effect on forage quality.

Weight ratios of plant parts varied $(P<0.05)$ in different phenological stages. F. ovina had elegant and thin stems in the 3rd stage of phenology while it still had a lot of leaves. Thus, the ratio of leaves for this species was higher than stems and flowers, even when its growth was completed. In contrast, stems in $H$. bulbosum were long and stout in the $3 \mathrm{rd}$ phenological stage. Leaves of $A$. tauri and A. trichophorum grew at the same time as stems. The ratio of stems and leaves was equal for A. tauri and slightly different in A. trichophorum. Leaves in $B$. tomentellus did not grow much during the $3 \mathrm{rd}$ phenological stage. Because of that, the ratio of stems was higher than the ratio of its leaves. Ghodsi Rasi and Arzani (1997) reported that the ratio of leaves to stems is an important factor affecting plant palatability during the 1st and 2nd stage of growth. In the 3rd growth stage, plants become fibrous and animals consume relatively the same amount of different parts of the plants. At this time, palatability of most species decreases. The research of Akbarinia and Koocheki (1992) showed that leaves made up more than $70 \%$ of forage of barley (Hordeum vulgare) at the beginning of the flowering stage, but it was reduced when plants matured. Percentage of spikes increased from 8.6 to 37.75 when growth of barley was completed.

Flower weight ratios varied in the 2 nd and 3 rd stages. Agropyron spp. assembled flowers and glumes remained on the plant when seed matured. Thus, flower ratios of these species in the 2nd and 3rd phenological stages were not significantly different. However, in the other 3 species, spikelets are shed after maturity, and the ratio of flowers in forage was lower in the 3rd stage of phenology than in the 2nd stage. But differences were not significant $(P<0.05)$.

Because forage with a higher leaf-to-stem ratio would result in better animal performance, it should be a factor when selecting the correct time of grazing. However, the amount of reserved soluble carbohydrates in the plant should be sufficient for future regrowth. A suitable grazing system should be applied to avoid overgrazing and damage to plants and to encourage plant reproduction.

Seasonal changes of CP during different phenological stages were reported by White (1983), Akbarinia and Koocheki (1992), and Arzani et al (1998). They found that when plants became older, CP declined. In this study, CP of stems, leaves, and flowers was different $(P<0.05)$ between phenological stages. Results also showed differences $(P<0.05)$ between $\mathrm{CP}$ in leaves, stems, and flowers of all species in all growth stages, except between leaf and stem of A. tauri and H. bulbosum in the 3rd growth stage.

Acid detergent fiber and NDF of stems were higher compared with leaves. Stems contain more fibers compared with leaves, which generally form from parenchyma tissues. Young plant cells have 1 external layer called a primary cell wall, but when they become mature, a secondary cell wall is also formed. Because of storage tissues in seeds, ADF and NDF contents varied with seed maturity between phenological stages and species. Arzani et al (2001) also reported that with progress

Table 6. Variation in metabolizable energy (ME, MJ/kg) between species and within and among plant parts and phenological stages of Agropyron tauri (Agta), Agropyron trichophorum (Agtr), Bromus tomentellus (Brto), Festuca ovina (Feov), and Hordeum bulbosum (Hobu).

\begin{tabular}{|c|c|c|c|c|c|c|c|c|}
\hline \multicolumn{9}{|c|}{ Variation in $\mathrm{ME}(\mathrm{MJ} / \mathrm{kg})^{1}$} \\
\hline \multirow[b]{2}{*}{ Species } & \multicolumn{2}{|c|}{ Vegetative } & \multicolumn{3}{|c|}{ Flowering } & \multicolumn{3}{|c|}{ Maturity } \\
\hline & Leaf & Stem & Leaf & Stem & Flower & Leaf & Stem & Flower \\
\hline Agta & $8.5 \mathrm{aAw}$ & 7.3 bAwy & 7.8 aBwy & $6.44 \mathrm{bBw}$ & $7.0 \mathrm{cAw}$ & $6.7 \mathrm{aCw}$ & $6.1 \mathrm{bCw}$ & $7.1 \mathrm{cAw}$ \\
\hline Agtr & $8.7 \mathrm{aAx}$ & 7.2 bAw & $7.7 \mathrm{aBw}$ & $6.26 \mathrm{bBw}$ & $6.8 \mathrm{cAw}$ & $7.0 \mathrm{aC} \times z$ & $5.9 \mathrm{bCw}$ & $6.6 \mathrm{cAx}$ \\
\hline Brto & $11.1 \mathrm{aAz}$ & $8.2 \mathrm{bAz}$ & $9.0 \mathrm{aBz}$ & $5.92 \mathrm{bBz}$ & $7.6 \mathrm{cAz}$ & $7.0 \mathrm{aCz}$ & $4.6 \mathrm{bCz}$ & $8.5 \mathrm{cBz}$ \\
\hline Feov & 8.4 aAw & $6.9 \mathrm{bAy}$ & $8.0 \mathrm{aBy}$ & $5.68 \mathrm{bBz}$ & $8.4 \mathrm{CAy}$ & $7.3 \mathrm{aCy}$ & $5.1 \mathrm{bCy}$ & $7.5 \mathrm{aBy}$ \\
\hline Hobu & $8.9 \mathrm{aAv}$ & $8.4 \mathrm{bAv}$ & $8.3 \mathrm{aBv}$ & $6.45 \mathrm{bBw}$ & $8.4 \mathrm{aAy}$ & $6.6 \mathrm{aCw}$ & $4.9 \mathrm{bCz}$ & $8.0 \mathrm{cBv}$ \\
\hline
\end{tabular}

1 Plant part means within a species and a phenological stage followed by the same lowercase letter $(a, b, c)$ are not significantly different $(P>0.05)$. Phenological stage means within a species and a plant part followed by the same uppercase letter $(A, B, C)$ are not significantly different $(P>0.05)$. Species means within a phenological stage and a plant part followed by the same lowercase letter $(v, w, x, y, z)$ are not significantly different $(P>0.05)$. 
of plant growth, ratios of protector and firmness tissues, which mostly consist of structural carbohydrates such as celluloses, hemicelluloses, and lignin, are increased. Therefore, maturity of plants and an increase in structural carbohydrates cause higher fiber amounts in forage late in the growing season.

Dry matter digestibility of plant parts mainly decreased with growth progress, and DMD of leaves, stems, and flowers for all species in all phenological stages were different. This agreed with results obtained by Akbarinia and Koocheki (1992). They reported that a reduction of DMD with maturity of plants is due to increasing structural tissues in stems. They also stated that increasing DMD of flowers in some grass species when seeds are mature is due to relatively high amounts of digestible carbohydrates in seeds. Pinkerton (1996) also reported a close relationship between digestibility and cell wall characteristics. He showed that cell contents could be $100 \%$ digestible and will not reduce even when the plant becomes mature. In contrast, the chemical structure of cell walls changes with plant growth. As plant growth continues, fiber content increases and digestibility decreases. Reduction of digestibility in matured plants also was reported by Kashki (2001), Erfanzadeh (2001), Rayburn (1997), and Linn and Kuehn (1994).

Plants growth reduced metabolizable energy content of leaves and stems. In flowers, in spite of an increase of fiber in the 3rd stage of growth from the formation of seeds, variation of ME was not considerable. In all species, differences $(P<0.05)$ were observed between the ME component of stems, leaves, and flowers within phenological stages. This agreed with the findings of Arzani et al (2001). Bashari et al (2001) reported that in rangelands with fair condition, but not in rangelands with poor condition, the ME requirements of grazing animals have been in balance with forage. Asadi Moghaddam et al (2000) suggested that increasing ME rate resulted in higher daily animal gain $(P<0.05)$ in their experiments.

\section{Conclusions}

Phenological stage of growth had a significant influence on forage quality. Therefore, forage quality of different parts of plants varied with phenological stage. With increased plant development, CP, DMD, and ME were reduced. Higher forage quality was recorded for the 1 st stage of growth. Within plant parts, leaves showed higher forage quality. Among the species, leaves of $B$. tomentellus had better quality than other species. In addition to forage quality, anatomic and morphologic characteristics of plants are also important for palatability of species. According to the results, the most suitable time to begin grazing is when the plant has desirable quantity and quality of forage with a higher leaf ratio.

\section{Literature Cited}

[AOAC] Association of Official Analytical Chemists. 1980. Official methods of analysis. 13th ed. Washington, DC: AOAC.

Arzan H., A. Nikkhah, and Z. Arzanı. 1998. Forage quality in three provinces of Semnan, Markazi and Lorestan Rangelands, Final report, Determining economic property size project. Tehran, Iran: College of Natural Resources, University of Tehran.
Arzani, H., J. Torkan, M. Jafari, and A. Nikkhah. 2001. Investigation on effects of phenological stages and environmental factors (soil and climate) on forage quality of some important range species. Journal of Agricultural Sciences 32:385-397.

AKBARINIA, A. AND A. KOOCHEKI. 1992. Investigation on effects of different harvesting stages on growth, productivity and quality of some barley's varieties. Journal of Pejouhesh and Sazandegi 15:40-43.

Asad Moghaddam, R., K. Jafari Khorshidi, and A. Nikkhah. 2000. Effects of energy and protein levels on performance of Kordy lambs. Journal of Pejouhesh and Sazandegi 46:110-113.

Bashari, H., M. R. Moghaddam, A. Sanadghol, and H. Amanlo. 2001. Investigation on quantity and quality of forage and animal requirement balance in some rangelands with different condition. Proceedings of the 1st National Livestock and Rangeland Management Congress. Research Institute of Forests and Rangelands of Iran. p 72.

Cochran, W. G. And G. M. Cox. 1957. Experimental designs. 2nd ed. New York, NY: John Wiley and Sons. 630 p.

Erfanzadeh, R. 2001. Investigation on qualitative indices changes of rangeland species during two phenology stages. Proceedings of the 1st National Livestock and Rangeland Manágement Congress. Research Institute of Forests and Rangelands of Iran. p 60.

Ghadaki, M. B., P. J. Vansoest, R. C. McDowell, and B. Malekpour. 1974. Composition and in-vitro digestibility of some arid zone forage from Iran. 12th International Grassland Congress, Moscow, Russia. Volume 3, Part 1. p 542-549.

GhodsI RASI, H. AND H. ARzani. 1997. Investigation on effective factors on palatability of some important range species in Charbagh region of Gorgan. Journal of Pejouhesh and Sazandegi 36:50-53.

GHOORCHI, T. 1995. Determination of chemical composition and dry matter digestibility of dominate species in Isfahan Province [thesis]. Industrial University of Isfahan, Iran. 80 p.

Harrocks, D. and J. F. Valentine. 1999. Harvested forage. San Diego, CA: Academic Press. $425 p$.

HemmatI, A. 1997. Report of adaptability study of range species in Zagheh region. Research Institute of Forests and Rangelands of Iran. Tehran. 87 p. Report Number 1376-173.

JafaRI, M. 1993. Determination of dry matter digestibility of some rangeland species by in vitro analysis. Journal of Pejouhesh and Sazandegi 18:66-68.

KASHKI, V. 2001. Determination of chemical composition of 7 Atriplex species in Sabzevar Research Station. Proceeding of the 1st National Livestock and Rangeland Management Congress. Research Institute of Forests and Rangelands of Iran. p 30.

LangeR, R. H. M. 1979. How grasses grow, 2nd ed. London, UK: Edward Arnold. Translated by S. Sanadgol. 1989. Tehran, Iran: Institute of Forests and Rangelands of Iran. 114 p.

Linn, J. AND C. KUEHN. 1994. The effects of forage quality on performance and cost of feeding lactating dairy cows. University of Minnesota, Department of Animal Science. St. Paul, MN. 9 p.

McDonald, P., R. A. Edvards, J. F. D. Greenhalgh, and C. A. Morgan. 1995. Animal nutrition. 5th ed. New York, NY: Longman Scientific \& Technical. 597 p.

Mobayen, S. 1980. Plants of Iran. Tehran, Iran: University of Tehran. 502 p.

OddY, V. H., G. E. Robards, and S. G. Low. 1983. Prediction of in vivo dry matter digestibility from the fiber and nitrogen content of a feed. Glenfield, New South Wales, Australia: Department of Agriculture, Nutrition and Feeds Evaluation Unit, Veterinary Research Station. p 395-398.

Pinkerton, B. 1996. Forage quality. Clemson, SC: Crop and Soil Environment Science Department, College of Agriculture, Forest, and Life Science, Clemson University. 998 p.

RAYBURN, E. B. 1997. Forage quality-fiber and energy. Morgantown, WV: West Virginia University Cooperative Extension Service. Available at http://www.caf.wvu.edu/ forage/5012.htm

WHITE, L. M. 1983. Seasonal changes in yield, digestibility, and crude protein of vegetative and floral tillers of two grasses. Journal of Range Management 36:402-404. 